\title{
Uji Aktivitas Antibakteri Minyak Atsiri Dan Ekstrak Etanol Bunga Kamboja Putih (Plumeria acuminata L.) Terhadap Eschericia coli
}

\author{
Prihardini $^{1}$, Ida Kristianingsih ${ }^{2}$ \\ Fakultas Farmasi Institut Ilmu Kesehatan Bhakti Wiyata Kediri, Jawa Timur \\ Email : heryaardini@yahoo.com
}

\begin{abstract}
ABSTRAK
Kamboja putih (Plumeria acuminata 1.) Merupakan tanaman yang sudah sejak lama dikenal masyarakat indonesia sejak lama dan digunakan sebagai obat tradisional untuk mengobati berbagai macam penyakit. Tumbuhan ini mengandung fulvoplumierin, yang memperlihatkan daya mencegah pertumbuhan bakteri, selain itu juga mengandung minyak atsiri. Penelitian ini bertujuan untuk mengetahui aktivitas antibakteri minyak atsiri dan ekstrak etanol bunga kamboja putih (Plumeria acuminata 1.) Terhadap bakteri Eschericia Coli dengan difusi kertas metode cakram. Minyak atsiri bunga kamboja didapatkan dengan menggunakan metode destilasi air dan uap. Hasil penelitian menunjukkan bahwa minyak atsiri bunga kamboja putih menunjukkan adanya aktivitas antibakteri pada konsentrasi $1 \%, 10 \%, 20 \%$ dan 30\% dengan diameter zona hambat berturut-turut $7.67 \mathrm{~mm}, 9.99 \mathrm{~mm}, 12.38 \mathrm{~mm}$ dan 13,26mm. Sedangkan ekstrak etanol bunga kamboja putih menunjukkan aktivitas antibakteri pada konsentrasi $1.25 \%, 2.5 \%$ dan $5 \%$ dengan zona hambat berturut-turut sebesar $6.1 \mathrm{~mm}, 6.7 \mathrm{~mm}$ dan $8 \mathrm{~mm}$.
\end{abstract}

Kata kunci : aktivitas antibakteri, minyak atsiri, ekstrak etanol, bunga kamboja putih (Plumeria acuminata 1.), Eschericia coli.

\begin{abstract}
White frangipani (Plumeria acuminata 1.) Is a plant that has long been known by indonesian people for a long time and it is used as a traditional medicine to treat various diseases. This plant contains fulvoplumierin, it have been showed as antibacterial activity and it also contains essential oils. This study was aim to determine the antibacterial activity of essential oil and ethanol extract of frangipani flowers (Plumeria Acuminata 1.) Against the bacteria escherichia coli by paper diffusion method. White frangipani flower essential oil obtained by water and steam distillation. The results showed that white frangipani flower essential oil showed antibacterial activity at a concentration of $1 \%$, $10 \%, 20 \%$ and $30 \%$ with a diameter of inhibition zone respectively $7.67 \mathrm{~mm}, 9.99 \mathrm{~mm}$, $12.38 \mathrm{~mm}$ and $13,26 \mathrm{~mm}$. While the ethanol extract of white frangipani flower antibacterial activity at concentrations of $1.25 \%, 2.5 \%$ and $5 \%$ with diameter of inhibition zone respectively $6.1 \mathrm{~mm}, 6.7 \mathrm{~mm}$ and $8 \mathrm{~mm}$.
\end{abstract}

Keyword : antibacterial test, essential oil, ethanol extract, white frangipani flower (Plumeria acuminata 1.), Eschericia coli. 


\section{PENDAHULUAN}

Sejak jaman dahulu tamaman digunakan secara luas sebagai sumber pengobatan. Berbagai penelitian sudah dilakukan pada beberapa dekade terakhir terutama terhadap tanaman yang sudah disebutkan pada literatur kuno yang sudah banyak digunakan pada obat tradisional [1]. Tanaman kamboja putih (plumeria acuminata 1.), merupakan tanaman yang sering di jumpai di indonesia. Kamboja termasuk dalam familia apocynaceae merupakan tanaman khas iklim tropis sehingga indonesia menjadi tempat pertumbuhan yang cocok [2].

Kamboja putih diketahui memiliki kandungan zat aktif antara lain steroid, fulvoplumierin, flavonoid, tanin, alkaloid dan glikosida. Selain itu kamboja putih juga mengandung minyak atsiri sekitar $0.04-0.07 \%$ dengan kandungan utama alkohol, geraniol, citronellol, famesol, pheniletilalkohol. Berdasarkan penelitian sebelumnya kamboja putih memiliki beberapa aktifitas salah satunya antibakteri baik garam positif mapun negatif $[1,3]$.

Banyaknya kasus resistensi terhadap antibakteri sintetis maka dibutuhkan pengembangan dari antibakteri dari bahan alami [4]. berbagai penyakit timbuk akibat infeksi bakteri. Bakteri patogen selalu dianggap menjadi penyebab utama morbiditas dan mortalitas pada manusia sehingga perusahan farmasi berlomba-lomba menciptakan antibakteri baru [5]. Bunga kamboja putih (plumeria acuminata 1.) memiliki aktivitas antibakteri khususnya terhadap bakteri penyebab disentri. Tum buhan ini mempunyai aktivitas antibakteri terhadap Eschericia coli (E. coli) pada kadar 1600-4000 ppm. Minyak atsiri dari bunga kamboja mempunyai aktivitas antibakteri terhadap bakteri gram positif (b. Subtilis) dengan zona hambat rata-rata diatas $20 \mathrm{~mm}$ pada konsentrasi sampel $20 \%$ [6].

Analisis GC-SM menunjukkan bahwa minyak atsiri bunga kamboja putih memiliki 19 senyawa[7]. Senyawa alkohol golongan fenol merupakan komponen yang paling aktif sebagai antibakteri di dalam kandungan minyak atsiri [8].

Tujuan dari penelitian adalah untuk mengetahui apakah ekstrak dan minyak atsiri bunga kamboja putih memiliki aktivitas antibakteri terhadap bakteri $E$ coli dengan menggunakan metode cakram. Hasil yang diperoleh diharapkan menjadi data yang relevan untuk penelitian selanjutnya.

\section{METODE PENELITIAN}

\section{Bahan}

Bunga kamboja putih (plumeria acuminata l.) Diperoleh dari daerah ngimbang, lamongan, kultur bakteri Eschericia coli ATCC 25922, Tween 80, Mueller Hinton Agar (MHA), Mueller Hinton Broth (MHB), Kloramfenikol, larutan $\mathrm{NaCl} 0.9 \%$ steril dan aquadest steril, pelarut etanol, metanol, reagen Mayer $(\mathrm{KI}$ dan $\mathrm{HgCl})$, reagen Dragendorff , reagen Liebermann-Burchard dan reagen wagner (I2 dalam KI), CMC-Na kertas saring, alkohol 70\%, Kloroform dan kertas cakram

\footnotetext{
Alat

Destilator air dan uap, mikropipet, inkubator, autoclave, LAF (Laminer Airflow), oven, kertas cakram, cawan petri, jarum ose, tabung reaksi, beaker glass, pinset, pembakar spiritus, pembakar bunsen, kapas lidi steril, dan jangka sorong, Rotary evaporator, cawan petri, erlenmeyer, labu ukur, gelas ukur, timbangan dan penyemprot, perangkat destilasi
} 


\section{Prosedur}

\section{Determinasi tanaman}

Determinasi bunga kamboja putih dilakukan di upt Balai Konservasi Tumbuhan Kebun Raya Purwodadi, Pasuruan,Jawa Timur.

\section{Pembuatan ekstrak etanol}

Ekstraksi serbuk simplisia dilakukan dengan metode maserasi menggunakan pelarut etanol $70 \%$. Sebanyak $\pm 1 \mathrm{~kg}$ sampel bunga kamboja putih dibersihkan, dikeringanginkan, dihaluskan dan dimaserasi dengan pelarut etanol selama $3 \times 24$ jam. Proses maserasi dilakukan berulang-ulang sampai diperoleh larutan jernih. Selanjutnya disaring, fitrat diuapkan dengan rotary evaporator untuk menghasilkan ekstrak pekat. Ekstrak yang diperoleh ditentukan rendemennya dengan cara berat ekstrak dibagi dengan berat sampel awal dan dikali seratus persen.

\section{Uji bebas etanol}

Ekstrak maserasi di uji bebas etanol $70 \%$ dengan penamabahan asam asetat dan asam sulfat dan dibantu dengan pemanasan. Ekstrak dinyatakan bebas etanol bila tidak ada bau aster yang khas dari etanol [9].

\section{Uji fitokimia}

Alkaloid : ekstrak digerus dan dibasakan dengan amonia sampai basah. Selanjutnya ditambahkan $10 \mathrm{ml}$ Kloroform, dan disaring. Filtrat yang dihasilkan ditambahkan asam klorida $5 \mathrm{n}$ sebanyak $10 \mathrm{ml}$, dikocok kuat-kuat, didiamkan sampai larutan asam klorida dan kloroform memisah. Lapisan asam klorida diambil dan dibagi dalam tiga tabung, dimana masing-masing tabung diuji untuk mengetahui keberadaan alkaloid dengan menggunakan reagen Mayer, reagen Dragendorff dan reagen Wagner.

Steroid, terpenoid dan saponin : sebanyak 2-4 gram sampel segar bunga kamboja putih dihaluskan, selanjutnya diekstraksi dengan metanol panas. Filtrat yang diperoleh dipekatkan dengan rotary evaporator sehingga diperoleh ekstrak metanol pekat. Ekstrak etanol kemudian diekstraksi lagi dengan $n$-Heksana. Fraksi yang larut dalam metanol kemudian diuji dengan pereaksi Liebermann- Burchard. Bila berwarna merah positif adanya triterpenoid. Bila berwarna hijau atau biru positif adanya steroid. Fraksi yang tidak larut dalam metanol ditambahkan sedikit air dan dikocok kuat-kuat, jika adanya busa yang stabil selama 30 menit menunjukkan adanya saponin. Selanjutnya larutan saponin tersebut dihidrolisis dengan $\mathrm{HCl}$, kemudian diuji dengan pereaksi Liebermann-Burchard. Bila berwarna merah atau ungu positif adanya saponin triterpenoid. Bila warnanya hijau atau biru positif adanya saponin steroid.

Flavonoid : ekstrak etanol di tamabahkan dengan logam $\mathrm{mg}$ dan $1 \mathrm{ml} \mathrm{HCl}$ pekat kemudian dikocok positif ditandai dengan terbentuknya warna merah, jingga, atau ungu [10].

\section{Pembuatan minyak atsiri}

Minyak atsiri bunga kamboja adalah hasil dari proses penyulingan dengan air dan uap, kemudian dilakukan proses pemisahan minyak atsiri dari air dengan menggunakan corong/tangki pemisah dan pemberian $\mathrm{Na}_{2} \mathrm{So}_{4}$ anhidrat.

Bunga kamboja segar dibersihkan dan dimasukkan ke alat destilator air dan uap yang sudah diisi air sebanyak $\pm 4000 \mathrm{ml}$. Proses destilasi dilakukan selama 3-4 jam. Hasil proses penyulingan yang tertampung akan memisah berupa minyak dan air. Minyak 
atsiri yang sudah dipisahkan kemudian diberi natrium sulfat eksikatus untuk menghilangkan sisa air.

\section{Uji antibakteri}

\section{Pembuatan media}

Media yang digunakan adalah media Mueller Hinton Agar (MHA) dengan komposisinya casein hidrolysate $17,5 \mathrm{~g}$, beef extract $300 \mathrm{~g}$, starch $1,5 \mathrm{~g}$, dan agar 17 g. Media yang digunakan dibuat dalam 2 tahap. Pembuatan media MHA dengan cara melarutkan 6.8 gram bubuk MHA ke dalam $200 \mathrm{ml}$ aquades, kemudian dipanaskan selama 1 menit. Selanjutnya disterilkan dalam autoklaf pada suhu $121^{\circ} \mathrm{C}$ selama 15 menit dan didinginkan sampai sekitar $40^{\circ}-45^{\circ} \mathrm{C}$. Media A yang telah disterilkan dituang dalam cawan petri $\pm 10 \mathrm{ml}$ secara aseptik dan dibiarkan padat. Media B digunakan untuk inokulasi bakteri, dibuat dengan melarutkan MHA sebanyak 3.4gram dilarutkan dalam $100 \mathrm{ml}$ aquades, kemudian dipanaskan sampai semua larut. Media dibagi dalam erlenmeyer $50 \mathrm{ml}$ masing-masing $5 \mathrm{ml}$, kemudian disterilkan dalam autoklaf pada suhu $121^{\circ} \mathrm{C}$ selama 15 menit, selanjutnya didinginkan sampai sekitar suhu $40^{\circ} \mathrm{C}$. Kemudian ditambahkan $1 \mathrm{ml}$ suspensi bakteri ke dalam media tersebut dan dihomogenkan. Media B tersebut dituangkan ke atas media $\mathrm{A}$, serta digoyangkan hingga merata dan dibiarkan membeku.

\section{Pengujian daya antibakteri}

Minyak atsiri bunga kamboja putih dilakukan replikasi sebanyak tiga kali dengan konsentrasi 1, 10, 20, 30, dan 40\% dalam Tween 80 5\% dan aquadest steril. Sebagai kontrol negatif digunakan larutan Tween 80 5\% dan aquadest steril tanpa penambahan sampel, sedangkan sebagai kontrol positif digunakan kloramfenikol 30 ppm.

Bakteri yang telah diremajakan dalam media Mueller Hinton Broth (MHB) distandardkan dengan Mc.Farland 0.5 kemudian ditanam diatas media Mueller Hinton Agar (MHA) dengan metode swab. Kertas Cakram yang telah direndam dalam masing-masing konsentrasi diletakkan pada permukaan media agar yang telah ditumbuhi bakteri. Aktivitas antibakteri yang dimiliki masing-masing minyak atsiri diamati berdasarkan diameter zona hambat (zona bening) yang terbentuk di sekeliling kertas cakram. Hasil diukur menggunakan jangka sorong.

\section{HASIL DAN PEMBAHASAN}

Bunga kamboja putih memiliki berbagai kandungan senyawa fitokimia yang diantaranya bisa digunakan sebagai antibakteri. Senyawa fitokimia merupakan senyawa kimia metabolit sekunder dari tiap tanaman. Sebelum dilakukan pengujian terlebih dahulu dilakukan determinasi dengan tujuan untuk menghindari kesalahan dalam pengambilan sampel. Determinasi tanaman dilakukan di UPT Balai Konservasi Tumbuhan Kebun Raya Purwodadi. Hasil identifikasi menunjukkan bahwa sampel yang digunakan merupakan bunga kamboja putih (Plumeria acuminata l.).

\section{Pembuatan simplisia}

Bunga kamboja putih yang digunakan dipilih yang masih segar supaya diperoleh kandungan yang maksimal.

\section{Rendemen ekstrak}

Rendemen ekstrak maupun minyak atsiri dihitung dengan cara membandingkan jumlah ekstrak yang diperoleh dengan simplisia awal yang digunakan. Rendemen ekstrak dapat 
digunakan sebagai parameter standar mutu ekstrak dan minyak atsiri pada tiap bets produksi maupun parameter efisiensi ekstraksi.

Hasil ekstraksi menunjukan bahwah bunga kamboja putih menunjukkan bahwa hasil rendemen dari ekstrak bunga kamboja putih adalah 8,7\% sedangkan hasil rendemen dari minyak atsiri bunga kamboja putih (Plumeria acuminata l.) Adalah $0.023 \%$.

Tabel 1. Hasil organoleptis rendemen ekstrak etanol dan minyak atsiri bunga kamboja putih

\begin{tabular}{cccccc}
\hline \multirow{2}{*}{ No } & \multirow{2}{*}{ Sampel } & \multicolumn{4}{c}{ Organoleptis } \\
\cline { 3 - 6 } & & Bentuk & Bau & Warna & rasa \\
\hline \multirow{2}{*}{ 1. } & Minyak Atsiri Bunga & cairan & aromatik khas & kuning & manis, agak \\
& Kamboja Putih & kental & bunga kamboja & kecoklatan & pedas \\
2. & Ekstrak bunga & cairan & aromatik khas & coklat tua & khas \\
\hline
\end{tabular}

\section{Uji fitokimia}

Uji fitokimia dilakukan untuk mengetahui kandunga apa saja yang terdapat dalam ekstrak bunga kamboja putih tersebut yang berperan mengambat pertumbuhan bakteri E.coli. Dari ahsil uji fitokimia didapatkan kandungan pada ektrak kamboja putih adalah terpenoid, flavonoid, tanin dan sedikit saponin.

\section{Tabel 2.hasil uji fitokimia ekstrak etanol bunga kamboja putih (Plumeria} acuminata)

\begin{tabular}{cccc}
\hline No & Uji fitokimia & Segar & Ekstrak \\
\hline 1 & Alkaloid & + & - \\
& Mayer & + & - \\
& Dragendroff & + & - \\
& Wegner & + & - \\
2 & Terpenoid & + & ++ \\
3 & Saponin & + & + \\
4 & Flavonoid & + & ++ \\
5 & Tanin & + & ++ \\
\hline
\end{tabular}

Dari hasil uji fitokimia menunjukkan bahwa bahwa kandungan yang terdapat pada ekstrak bunga kamboja adalah flavonoid, terpenoid, tanin dan sedikit saponin. Flavonoi dan terpenoid adalah kandungan terbesar yang kemungkinan memiliki aktivitas antibakteri. Mekanisme kerja flavonoid berfungsi sebagai antibakteri dengan cara membentuk senyawa kompleks terhadap protein extraseluler yang mengganggu keutuhan membran sel bakteri. Mekanisme kerjanya dengan cara mendenaturasi protein sel bakteri dan merusak membran sel tanpa dapat diperbaiki lagi [11]. Mekanisme triterpenoid sebagai antibakteri adalah bereaksi dengan porin (protein transmembran) pada membran luar dinding sel bakteri, membentuk ikatan polimer yang kuat sehingga mengakibatkan rusaknya porin. Rusaknya porin yang merupakan pintu keluar masuknya senyawa akan mengurangi permeabilitas membran sel bakteri yang akan mengakibatkan sel bakteri akan kekurangan nutrisi, sehingga pertumbuhan bakteri terhambat atau mati 
[12]. Mekanisme tanin sebagai antibakteri adalah menghambat enzim reverse transkriptase dan dna topoisomerase yang mengakibatkan tidak terbentuknya sel bakteri [10]

\section{Hasil uji antibakteri \\ Identifikasi Eschericia coli}

Bakteri E. coli diambil dari media pertumbuhan dengan menggunakan ose. Beberapa koloni $E$. coli diletakkan diatas gelas objek, dikeringkan dan difiksasi dengan api. Dan ditetesi crystal violet selama 5 menit. Zat warna dibuang dan diganti dengan larutan lugol (larutan $\mathrm{I}_{2}+\mathrm{KI}$ ) dibiarkan selama 45-60 detik. Larutan lugol dibuang dan sediaan dicuci dengan alkohol 96\% selama 30 detik atau digoyang-goyangkan sampai tidak ada zat warna yang mengalir lagi. Sediaan dicuci dengan air dan diwarnai dengan air fuchsin selama 1-2 menit. Sediaan dicuci, dikeringkan dan diperiksa di bawah mikroskop. Jika gram positif akan memberiakan warna ungu.

Sifat kuman terhadap pewarnaan gram merupakan sifat penting untuk membantu determinasi suatuvbakteri. Hasil pewarnaan gram yang dilakukan terhadap bakteri uji dalam penelitian tertera dalam Tabel 3 dan Gambar 1.

\section{Tabel 3. Identifikasi bakteri dengan pewarnaan}

\begin{tabular}{ccccc}
\hline Bakteri & Bentuk & Susunan & Warna & Sifat gram \\
\hline Eschericia coli & Batang & Menyebar & Merah & Negatif \\
\hline
\end{tabular}

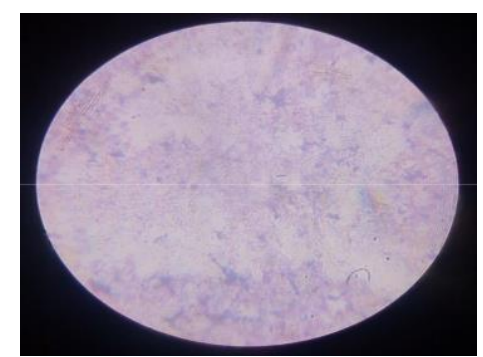

Gambar 1. Hasil pewarnaan gram Eschericia coli dibawah mikroskop

Uji aktivitas antibakteri merupakan uji yang digunakan untuk menentukan kepekaan bakteri patogen. Uji aktifitas antibakteri terhadap antimikrobia dapat dilakukan dengan salah satu dari dua metode pokok yakni dilusi atau difusi [13]. Pada uji antibakteri menggunakan ekstrak etanol dan minyak atsiri bunga kamboja putih digunakan metode difusi agar menggunakan kertas cakram. Kertas cakram berisi sejumlah tertentu obat ditempatkan pada medium padat yang sebelumnya telah diinokulasi bakteri uji pada permukaannya.

Pada pengukuran aktivitas antibakteri ini tidak menggunakan konsentrasi yang sama karena hanya ingin melihat apakah ekstrak dan minyak atsiri bunga kamboja putih keduanya memiliki aktivitas terhadap bakteri E. coli. Penggunaan konsentrasi yang berbeda baik dalam ekstrak etanol maupun minyak atsiri dimaksudkan untuk melihat ada tidaknya aktivitas antibakteri sehingga bisa digunakan untuk memperkirakan konsentrasi 
hambat minimalnya. Hasil uji aktivitas dapat dilihat dengan adanya zona radikal atau zona hambat yang merupakan daerah yang sama sekali tidak ada pertumbuhan bakteri E. coli disekitar cakram.

\section{Hasil uji ekstrak etanol bunga kamboja putih}

Ekstrak etanol bunga kamboja putih yang digunakan sebagai antibakteri dibagi dalam 3 konsentrasi yaitu 5\%, 2,5\%, 1,25\%. Pengujian menggunakan kertas cakram yang telah di beri perlakuan di letakan pada media bakteri tersebut dan didiamkan selama 24 jam untuk mengamati pertumbuhan bakteri untuk setiap area yang tidak ditumbuhi oleh bakteri. Sebagai kontrol positif digunakan ciprofloxacin $5 \mu \mathrm{g} / \mathrm{ml}$ dan untuk negatif digunakan CMC- Na 1\%. Zona hambat pada bakteri di ukur dengan menggunakan jangka sorong dalam satuan milimeter. Hasil pengukuran aktivitas antibakteri ekstrak etanol dapat dilihat pada Tabel 4.

Tabel 4. Ukuran rerata diameter zona hambat pertumbuhan bakteri E.coli pada berbagi perlakuan selama 24 jam pada media MHA

\begin{tabular}{lcccc}
\hline \multirow{2}{*}{\multicolumn{1}{c}{ Perlakuan }} & \multicolumn{3}{c}{$\begin{array}{c}\text { Diameter zona hambat } \\
(\mathbf{m m})\end{array}$} & \multirow{2}{*}{ Rata rata } \\
\cline { 2 - 4 } & $\mathbf{1}$ & $\mathbf{2}$ & $\mathbf{3}$ & \\
\hline Kontol positif & 20 & 22 & 24 & 22 \\
Kontol negatif & 6 & 6 & 6 & 6 \\
Ekstrak etanol 25\% & 8 & 8,2 & 8,4 & 8,2 \\
Ekstrak etanol 2,5\% & 6 & 7 & 7,2 & 6,7 \\
Ekstrak etanol 1,25\% & 6 & 6,2 & 6,3 & 6,1 \\
\hline
\end{tabular}

Penggunaan cakram tunggal pada setiap antibiotik dengan standardisasi yang baik, bisa menentukan apakah bakteri peka atau resisten dengan cara membandingkan zona hambat standar bagi obat yang sama. Daerah hambatan sekitar cakram yang berisi sejumlah tertentu antimikrobia tidak mencerminkan kepekaan pada obat dengan konsentrasi yang sama per millimeter medium, darah atau urin [14]. Berdasarkan data yang didapatkan terlihat bahwa konsentras $1.25 \%$ sudah dapat memberikan aktivitas antibakteri meskipun aktivitasnya lemah. Semakin tinggi konsentrasi ektrak maka daya hambatnya semakin besar.

\section{Hasil uji antibakteri minyak atsiri bunga kamboja putih}

Minyak atsiri bunga kamboja putih yang digunakan dalam pengujian dilarutkan dalam Tween 80 untuk dibuat dalam konsentrasi 1\%, 10\%, 20\% dan 30\%. Sebagai kontrol negatif digunakan Tween $805 \%$ dan aquadest steril tanpa penambahan sampel, sedangkan sebagai kontrol positif digunakan Kloramfenikol 30 ppm. Bakteri yang telah diremajakan dalam media Mueller Hinton Broth (MHB) distandardkan dengan mc.farland 0.5 kemudian ditanam diatas media Mueller Hinton Agar (MHA) dengan metode swab. Kertas cakram yang telah direndam dalam masing-masing konsentrasi diletakkan pada permukaan media agar yang telah ditumbuhi bakteri. Aktivitas antibakteri yang dimiliki masing-masing minyak atsiri diamati berdasarkan diameter zona hambat (zona bening) yang terbentuk di sekeliling cakram. Hasil pengukuran aktivitas antibakteri minyak atsiri dapat dilihat pada tabel 5 
Tabel 5. Ukuran rerata diameter zona hambat pertumbuhan bakteri e.coli pada berbagi perlakuan selama 24 jam pada media mha

\begin{tabular}{lcccc}
\hline \multirow{1}{*}{ Perlakuan } & \multicolumn{3}{c}{ Diameter zona hambat } & \multirow{2}{*}{ Rata rata } \\
\cline { 2 - 4 } & $\mathbf{1}$ & $\mathbf{2}$ & $\mathbf{3}$ & \\
\hline Kontol positif & 25,8 & 22,45 & 22,25 & 23,5 \\
Kontol negatif & 0 & 0 & 0 & 0 \\
Minyak atsiri 30\% & 13,75 & 14,13 & 13 & 13,26 \\
Minyak atsiri 20\% & 12,5 & 13 & 12,65 & 12,71 \\
Minyak atsiri 10\% & 8,63 & 10 & 10,35 & 9,66 \\
\hline
\end{tabular}

Hasil penelitian menunjukkan bahwa pada konsentrasi $1 \%$ minyak atsiri bunga kamboja putih sudah menunjukkan aktivitas antibakteri. Semakin besar jumlah konsentrasi minyak atsiri maka semakin lebar diameter luas daerah hambatan. Hal ini diduga disebabkan karena adanya kandungan terpen ataupun alkohol yang sebagai zat aktif antibakteri dalam minyak atsiri h [7].

\section{KESIMPULAN}

1. Ekstrak etanol bunga kamboja putih menunjukkan aktivitas antibakteri pada konsentrasi $1.25 \%, 2.5 \%$ dan $5 \%$ dengan zona hambat berturut-turut sebesar 6,1 $\mathrm{mm}, 6,7 \mathrm{~mm}$ dan $8 \mathrm{~mm}$.

2. Minyak atsiri bunga kamboja putih menunjukkan adanya aktivitas antibakteri pada konsentrasi $1 \%$, 10\%, dan $20 \%$ dan $30 \%$ dengan diameter zona hambat berturutturut 7,67 mm, 9,99 $\mathrm{mm} \mathrm{12,38} \mathrm{mm}$ dan $13,26 \mathrm{~mm}$.

\section{DAFTAR PUSTAKA}

1. Choudhary, J ; Kumar, V \& Singh, S., 2014. Phytochemical And Pharmacological Activity Of Genus Plumeria: An Updated Review . International Journal Of Biomedical and Advance Research,Vol. 05 (06) , P 266-171

2. Firdaus, H \& Saputro, D.A., 2011. Pengambilan Minyak Dari Bunga Kamboja Dengan Metode Distilasi Air (Water Distillation). Laboratorium Teknologi Proses Kimia Jurusan Teknik Kimia FTI-ITS

3. Mursito, B. \& Prihmantoro, H., 2011, Tanaman Hias Berkhasiat Obat, Ed. Ke-4, Penebar Swadaya., Jakarta

4. Devprakash ; Tembare, R; Gurav, S; Kumar, S And Mani, T.T., 2012, An Review Of Phytochemical Constituents \& Pharmacological Activity Of Plumeria Species. International Journal Of Current Pharmaceutical Research, Vol 4, ( 1), P. 1-6

5. Djeussi, D.E; Noumedem, J. Ak; Seukep, J. A; Fankam, A.G; Voukeng, I.K; Tankeo, S.B; Nkuete, A.Hl And Kuete, V., 2013, Antibacterial Activities Of Selected Edible Plants Extracts Against Multidrug-Resistant Gram-Negative bacteria. Bmc complementary and alternative medicine, 13:164 p.1-8

6. Zaheer., 2010. Antimicrobial Activity Of Essential Oil Of Flowers Of Plumeria Alba Linn (Apocynaceae). International Journal Of Pharmacy and Pharmaceutical Sciences. Vol 2. Issue 4. Pg.155-157. 
7. Phang \& Vionita, D., 2010. Analisis Kualitatif Dan Kuantitatif Minyak Atsiri Dari Bunga Kamboja Putih (Plumeria acuminata W.T.AIT.) Dan Bunga Kamboja Merah (Plumeria rubra L.)

8. Pengelly, Andrew., 2004. The Constituens Of Medicinal Plants: An Introduction To The Chemistry and Therapeutics Of Herbal Medicine. National Library Of Australia

9. Praeparandi, A,. 1979. Card System dan Reaksi Warna. Institut Teknologi: Bandung.

10. Robinson, T., 1995. Kandungan Organik Tumbuhan Tinggi. Terjemahan:Kosasih Padmawinata. ITB.Bandung.

11. Juliantina., Farida R., 2009. Manfaat Sirih (Piper Crocatum) Sebagai Agen Antibakterial Terhadap Gram Positif Dan Gram Negatif. JKKI - Jurnal kedokteran dan Kesehatan Indonesia; No 1 (I).P.5.

12. Rachmawati, F., M.C. Nuria, Suamntri. 2010. Uji Aktivitas Antibakteri Fraksi Kloroform Ekstrak Etanol Pegagan (Centella Asiatica(L) Urb) Serta Identifikasi Senyawa Aktifnya. Universitas Wahid Hasyim. Semarang.

13. Jawetz, E., Melnick Dan Adelberg, E.A., 1996. Mikrobiologi Kedokteran. Diterjemahkan Oleh Dr. Edi Nugroho Dan Dr. Rf Maulany, Edisi 20, Jakarta: Egc Penerbit Buku Kedokteran. P. 141, 160, 211-215, 234-239 